Вісник Дніпропетровського університету. Серія: геологія, географія. 25 (1), 2017, 131 - 136.

Vìsnik Dnìpropetrovs'kogo unìversitetu. Serìa Geologîa, geographìâ

Dnipropetrovsk University Bulletin. Series: geology, geography. 25 (1), 2017, 131 - 136.

Doi: $10.15421 / 111714$

http://geology-dnu.dp.ua

УДК 556.332.4

\title{
Активізація гіпергенних процесів у водоносних горизонтах районів видобутку корисних копалин (на прикладі Північного гірничо-збагачувального комбінату, Кривбас)
}

\section{Н. П. Шерстюк}

Днепропетровський наџіональний університет імені Олеся Гончара, Дніпро, Україна, sherstuknp@inbox.ru

Проведено аналіз гідрогеохімічних процесів у воді водоносного горизонту четвертинних відкладів та території Північного гірничо-збагачувального комбінату за період 1978 - 2016 рр. Виконано розрахунки за результатами гідрогеохімічного моніторингу по 24 свердловинах. Виявлено закономірності у перебігу процесів гідролізу силікатів та алюмосилікатів у підземних водах на території, що вивчасться. Установлено, що переважаючими с процеси гідролізу до встановлення рівноваг із каолінітом, що свідчить про активізацію гіпергенних процесів у воді водоносного горизонту четвертинних відкладів.

Ключові слова: гірничо-збагачувальний комбінат, підземні води, гіпергенні прочеси, гідроліз силікатів та алюмосилікатів

\section{Activation of supergene processes in aquifers mining areas (for example the North mining and processing plant, Kryvbas)}

\author{
N. P. Sherstyuk \\ Oles Honchar Dnipropetrovsk National University, Dnipro, Ukraine, sherstuknp@inbox.ru
}

Mining and Mineral Engineering has a powerful impact on the environment. In the areas of mining taking place radical changes of geological environment that are irreversible. Groundwater, as part of the four component hydrogeological system undergo significant changes. The investigation hidrogeochemistry processes in the groundwater aquifer of quaternary sediments in the North mining plant. Investigated aquifer studied quaternary sediments, water containing loess loam, Valley Saksagan - alluvial sands. The aquifer distributed throughout the territory of studies. The most powerful man-made elements that have an impact on groundwater is storage of waste rock, industrial site, quarries and dumps. Research based on the results of hydrogeological monitoring carried out geological and hydrogeological Krivorozhskiy party since 1978. For selected research results of the monitoring of 24 wells. Analysis of observations of the chemical composition of groundwater in the North mining and processing plant and existing man-made objects showed that hydrogeochemical situation came into equilibrium-nonequilibrium nature. The purpose of the study is to assess and forecast of man-made mineral zone supergene iron ore deposits. Analysis of possible processes hydrolysis of silicates and aluminosilicates water aquifer of quaternary sediments. Found processes of transition to montmorillonite and kaolinite. Made construction of two-dimensional diagrams of the system $\mathrm{HCl}-\mathrm{H}_{2} \mathrm{O}-\mathrm{Na}_{2} \mathrm{O}-\mathrm{MgO}-\mathrm{SiO}_{2}$ at $\mathrm{t}=25{ }^{\circ} \mathrm{C}$ and $\mathrm{lg}\left[\mathrm{H}_{4} \mathrm{SiO}_{4}\right]=-3,99$ rezultatmy chemical analysis of water samples from wells. Built map-scheme of hydrolysis of silicates and aluminosilicates in the territory as of March 2016. Analysis of spatiotemporal distribution supergene processes showed their transient nature and strengthen over time. Calculations shown activation of supergene processes in water aquifer of quaternary sediments in the territory North mining and processing plant to establish equilibrium with kaolinite, resulting in increased salinity of groundwater, magnesium ion content and hardness.

Keywords: mining and processing plant, groundwater, supergene processes, hydrolysis of silicates and aluminosilicates

Вступ. Зараз досить добре вивчені екологічні проблеми, які виникають на територіях 3 інтенсивною гірничорудною промисловістю, де корисні копалини у процесі освоєння піддаються впливу різноманітних факторів по ходу реалізації технологічних ланцюжків. Мінеральна речовина при цьому піддається більш-менш глибокій трансформації як хімічного складу, так i фізичного стану. Досить активно відбуваються процеси типу окисного (гідролізного) деструктування мінералів. Послідовно формуються специфічні (нерідко токсичні) гази, розчини й тверді фази, які потім вступають у 
нові взаємодії 3 багатьма компонентами навколишнього середовища.

\section{Вивчення}

техногенного мінералоутворення має особливе значення у вирішенні питань охорони навколишнього середовища на територіях гірничо-промислових комплексів. Техногенна мінералізація безперечний індикатор багатьох процесів, що завдають шкоди не тільки навколишньому середовищу (підвищена концентрація токсичних речовин у водах, засоленість грунтів, присутність у будовах i конструкціях мінералізованих розчинів, інтенсивна корозія металів та ін.), а й здоров'ю людей, що живуть у рудних районах. Зрештою, на території освоєння родовища часто виникає досить напружений екологічний стан, що деформує умови життєдіяльності тваринного й рослинного світу (атмосфера, природні води, трофічні ланцюжки).

Аналіз основних досліджень і публікацій. В основу досліджень покладено принцип нерівноважності гідрогеохімічних систем, що був обгрунтований О. I. Перельманом (Perelman А.I., 1966). Причина нерівноважності вод, на думку О. I. Перельмана, полягає в постійному припливі енергії, носіями якої служать геохімічні акумулятори - вільні кисень, вуглець і водень органічних речовин.

Для визначення спрямованості процесів взаємодії між рідкою й твердою фазами й найбільш імовірних продуктів цього перетворення зараз усе ширше застосовуються методи термодинамічного аналізу. Подібний підхід у вивченні фізико-хімічної еволюції природних і природно-техногенних систем виходить із принципу локальних рівноваг, висунутого Д. С. Коржинським (Korzhinskiy D.S., 1982) і підтвердженого В. П. Звєрєвим (Zverev V.P., 1982), Ф. I. Тютюновою (Tjutjunova F.I., 1987), С. А. Шварцевим (Shvarcev S.L., 1988).

Мета дослідження. Аналіз результатів спостережень за хімічним складом грунтових вод на території Північного гірничо-збагачувального комбінату та існуючих техногенних об'єктів показав, що гідрогеохімічна ситуація набула рівноважно-нерівноважного характеру.

Мета роботи - оцінювання й прогноз техногенного мінералоутворення в зоні гіпергенезу залізорудних родовищ.

Матеріал і методи досліджень. 31978 року Криворізька геолого-гідрогеологічна партія на території Кривбасу проводить гідрогеологічний моніторинг. Тісна співпраця гідрогеологів цієї партії та науковців геолого-географічного факультету ДНУ імені Олеся Гончара триває понад 25 років, як у виконанні госпдоговорів, так i в наданні поточних консультацій щодо організації та проведення гідрогеологічного моніторингу. У 1991 - 1995 рр. виконувалися госпдоговори щодо створення та наповнення баз гідрогеологічних спостережень, у 2015 та 2016 pp. - виконано хімічні аналізи проб вод із свердловин, які належать до мережі гідрогеологічного моніторингу території Кривбасу.

Найбільше гідрогеологічної інформації накопичено щодо території Північного гірничозбагачувального комбінату (ПівнГЗК).

На даному етапі, який $є$ продовженням досліджень, розпочатих ще у 1991 р., виконано дослідження вторинного мінералоутворення у нерівноважних умовах водоносного горизонту четвертинних відкладів.

Результати та їх аналіз. Взаємодія між гірськими породами й природними водами можна розглядати як ряд окремих хімічних реакцій. Початковими продуктами цих реакцій $\epsilon$ будь-які вихідні мінеральні води, кінцевими вторинні мінерали, а також іони й нейтральні молекули, які перейшли у тверду фазу.

Застосовуючи основні поняття й закони термодинамічного аналізу (закон діючих мас, термодинамічні константи рівноваги), можна підійти до оцінки порівняльної агресивності природних вод стосовно будь-якого мінералу. Така величина показує ступінь нерівноважності природних вод із мінеральною речовиною. Агресивність природних вод розраховується для конкретної системи, що містить хімічні елементи, які входять до складу даного мінералу в стандартних умовах $\left(25^{\circ} \mathrm{C}, 10^{5}\right.$ Па).

Установлення ступеня агресивності будьяких типів природних вод стосовно мінералів дає можливість виявити найбільш імовірні мінеральні асоціації, стабільні в умовах даного гідрогеохімічного середовища.

Криворізький басейн - основний виробник залізорудної сировини в Україні. Наразі тут працюють 17 гірничо-збагачувальних підприємств, у тому числі 12 шахт і п'ять гірничо-збагачувальних комбінатів (ГЗК). У процесі видобутку й переробки залізних руд за понад 100 років накопичено значні обсяги розкривних порід у відвалах i відходах збагачення (хвостах) у хвостосховищах.

Територія ПівнГЗК у геоморфологічному відношенні приурочена до степової акумулятивно-денудаційної рівнини із загальним 
ухилом поверхні рельєфу у південно-східному напрямку до долини р. Саксагань. Абсолютні відмітки поверхні змінюються від 130,0 - 140,0 м на вододілах до 55,0 - 60,0 м у долині р. Саксагань. Велика частина територіï, що прилягає до хвостосховища, використовується як орні землі (Sherstyuk N.P., Nosova L.O., 2016).

Зона дослідження характеризується наявністю таких водоносних горизонтів:

- водоносний горизонт четвертинних відкладів у лесоподібних суглинках i в алювіальних відкладах заплави р. Саксагань;

- водоносний горизонт неоген-

палеогенових відкладів;

- водоносна зона тріщинуватих

кристалічних порід.

У лесоподібних суглинках до експлуатації хвостосховища зустрічалися окремі лінзи «верховодки» потужністю до $2-3$ м, що залягали на водотривких червоно-бурих глинах $\mathrm{i}$ суглинках. Тільки в балках були зустрінуті води балкового алювію. Широкий розвиток яровобалкової мережі виключав формування водоносного горизонту в четвертинних суглинках. Таким чином, особливість цього району полягає в тому, що до будівництва хвостосховища в 1962 р. тут практично був відсутнім водоносний горизонт у четвертинних суглинках. Утворився він у результаті господарської діяльності людини i має техногенне походження.

На території досліджень виявлено водоносний горизонт алювіальних четвертинних відкладів у заплаві р. Саксагань. Особливість його - це відсутність гідравлічного зв'язку 3 водоносним горизонтом лесоподібних суглинків, натомість можливий його зв'язок із річковими водами та водоносним горизонтом неогенових відкладів.

Відповідно до сучасних уявлень про формування хімічного складу підземних вод доцільно розглядати порізно надходження катіонів і аніонів у підземні води (White W. M., 2013). Катіонний склад води являє собою різницю між сполуками, що розчиняються, й породами, тобто має літогенну природу. Аніонний склад води не залежить від типу породи. Установлено, що у процесі формування аніонної сполуки підземних вод на досліджуваній території вирішальну роль відіграють шахтні води хлоридного складу, що фільтруються із хвостосховища, й підвищений вміст сульфатів у хвостах. Гідрокарбонатний іон найчастіше має підлегле значення.

На наш , формування катіонної сполуки підземних вод на досліджуваній території відбувається в основному в результаті процесу гідролізу алюмосилікатів водонасичених порід.

Гідроліз поєднує процеси взаємодії водневих і гідроксильних іонів води 3 різними твердими фазами (Tјutjunova F.I., 1987). Основними джерелами іонів $\mathrm{H}^{+}$i $\mathrm{OH}^{-} \epsilon$ сама вода як розчинник, кислоти й луги, що надходять із забрудненими атмосферними опадами та стічними водами $\mathrm{y}$ результаті хімічних $\mathrm{i}$ біохімічних процесів.

Гідроліз складається із взаємного хімічного розкладання твердої речовини й води. У переважній більшості випадків гідроліз алюмосилікатів відбувається шляхом повного переходу в розчин хімічних елементів із наступним їх осадженням у вигляді нових вторинних мінеральних фаз. таким чином підземні води перебувають постійно в ненасиченому стані щодо вихідних мінералів, які можуть розчинятися протягом усього часу їх взаємодії 3 підземними водами (Grimaud D., Beaucaire C., Michard G., 1990).

Розглянуто такі реакції гідролізу (Zverev V.P., 1982):

$$
\underset{\text { альбіт }}{7 \mathrm{NaAlSi}_{3} \mathrm{O}_{8}+6 \mathrm{H}^{+}+20 \mathrm{H}_{2} \mathrm{O}=} \underset{\text { Na-монтморилоніт }}{3 \mathrm{Na}_{0,333} \mathrm{Al}_{2,33} \mathrm{Si}_{3,67} \mathrm{O}_{10}(\mathrm{OH})_{2}+10 \mathrm{H}_{4} \mathrm{SiO}_{4}{ }^{0}+6 \mathrm{Na}^{+} ;}
$$

$$
\Delta \mathrm{G}_{\text {реак }}^{0}=-58,98 \text { кДж/моль }
$$

$$
\begin{gathered}
7 \mathrm{Mg}_{5} \mathrm{Al}_{2} \mathrm{Si}_{3} \mathrm{O}_{10}(\mathrm{OH})_{8}+68 \mathrm{H}^{+}+\mathrm{H}_{4} \mathrm{SiO}_{4}{ }^{0}=\underset{\text { хлорит }}{\mathrm{Mg-монтморилоніт}} \\
\text { Mg, }
\end{gathered}
$$

$$
\Delta \mathrm{G}_{\text {реак }}^{0}=-2693,11 \text { кДж/моль }
$$

$$
6 \mathrm{Na}_{0,33} \mathrm{Al}_{2,33} \mathrm{Si}_{3,67} \mathrm{O}_{10}(\mathrm{OH})_{2}+2 \mathrm{H}^{+}+23 \mathrm{H}_{2} \mathrm{O}=7 \mathrm{Al}_{2} \mathrm{Si}_{2} \mathrm{O}_{5}(\mathrm{OH})_{4}+8 \mathrm{H}_{4} \mathrm{SiO}_{4}{ }^{0}+2 \mathrm{Na}^{+} \text {; }
$$




$$
\begin{gathered}
\Delta \mathrm{G}_{\text {реак }}^{0}=96,97 \text { кДж/моль } \\
6 \mathrm{Mg}_{0,167} \mathrm{Al}_{2,33} \mathrm{Si}_{3,67} \mathrm{O}_{10}(\mathrm{OH})_{2}+2 \mathrm{H}^{+}+23 \mathrm{H}_{2} \mathrm{O}=7 \mathrm{Al}_{2} \mathrm{Si}_{2} \mathrm{O}_{5}(\mathrm{OH})_{4}+8 \mathrm{H}_{4} \mathrm{SiO}_{4}{ }^{0}+\mathrm{Mg}^{2+} .
\end{gathered}
$$

Мg-монтморилоніт

каолініт

$$
\Delta \mathrm{G}_{\text {реак }}^{0}=104,57 \text { кДж/моль }
$$

Реакції за рівняннями (1) та (2) відбуваються мимовільно при негативному значенні вільної енергії, реакції за рівняннями (3) та (4) (перехід до каолініту) мимовільно відбуватися не можуть, а мають потребу в хімічній енергії (Köhler S.J., Dufaud F., Oelkers E. H., 2003).

Найчастіше для вивчення процесів гідролізу застосовується метод плоских діаграм у двовимірних системах вмісту макрокомпонентів (Shvarcev S.L., 1988).

Розрахунки показують, що у воді водоносного горизонту четвертинних відкладів території Північного гірничо-збагачувального комбінату відбуваються процеси гідролізу силікатів і алюмосилікатів по рівняннях (2) і (4) (рис.1).

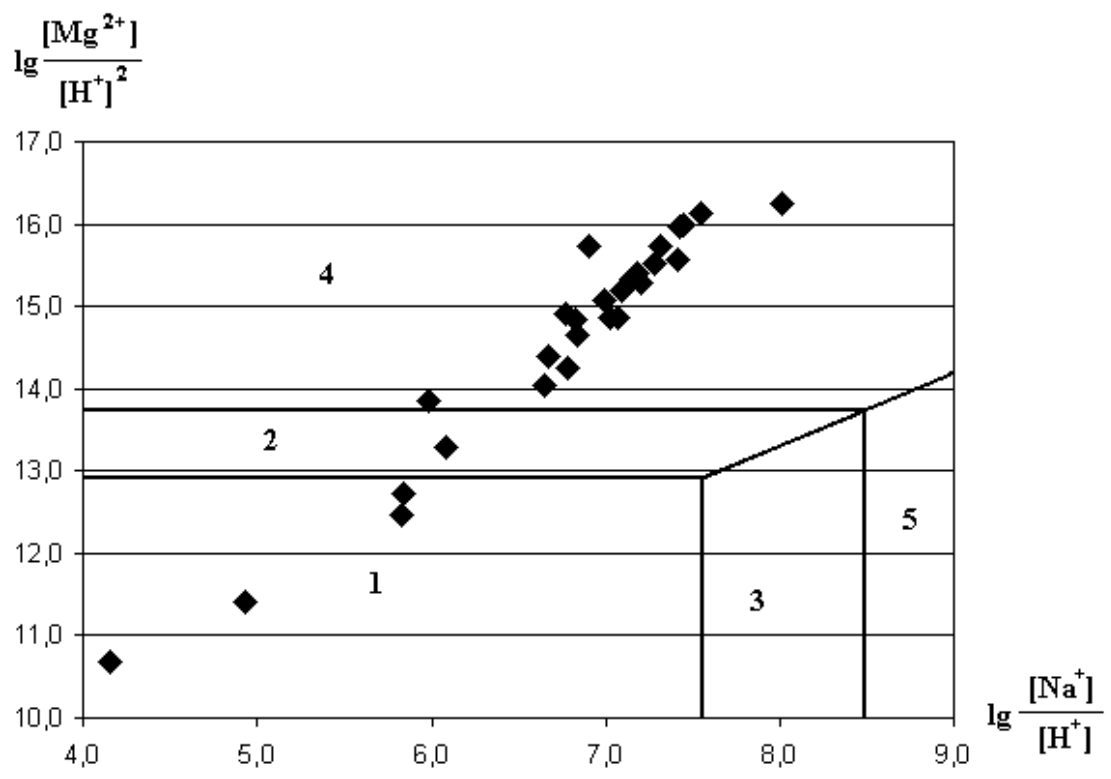

Рис. 1. Система $\mathrm{HCl}-\mathrm{H}_{2} \mathrm{O}-\mathrm{Na}_{2} \mathrm{O}-\mathrm{MgO}-\mathrm{SiO}_{2}$ за $\mathrm{t}=25^{\circ} \mathrm{C}$ i $\lg \left[\mathrm{H}_{4} \mathrm{SiO}_{4}\right]=-3,99$ з нанесеними даними хімічного складу води зі св. № 1052 за період з 1985 по 2016 рр.): номерами вказано поля стійкості мінералів: 1 - каолініт; 2 - Мgмонтморилоніт; 3 - Nа-монтморилоніт; 4 - хлорит; 5 - альбіт

У воді водоносного горизонту четвертинних відкладів на даній території встановлюються рівноваги або з каолінітом (поле 1), або з $\mathrm{Mg}$ монтморилонітом (поле 2), або із хлоритом (поле 4), рівноваги 3 Na-монтморилонітом і альбітом ніколи не встановлюються. Виявлена закономірність дозволяе перейти до вивчення процесів гідролізу силікатів і алюмосилікатів у часі (рис. 2).

Загальне уявлення про процеси гідролізу у воді водоносного горизонту четвертинних відкладів на території ПівнГЗК можна скласти, аналізуючи карту-схему наведеної на рисунку 3 .
На переважній більшості території ПівГЗК у воді водоносного горизонту четвертинних відкладів установлено рівноваги 3 каолінітом, у пробах води 315 свердловин (63\%). Рівноваги 3 монтморилонітом та хлоритом установлені у 5 (21\%) та 4 (16 \%) свердловинах відповідно. Закономірностей по площі у встановленні рівноваг не виявлено. Більш-менш прив'язані по площі поширення рівноваги у воді водоносного горизонту із хлоритом (територія промислового майданчика та рудозбагачувальної фабрики № 2). 


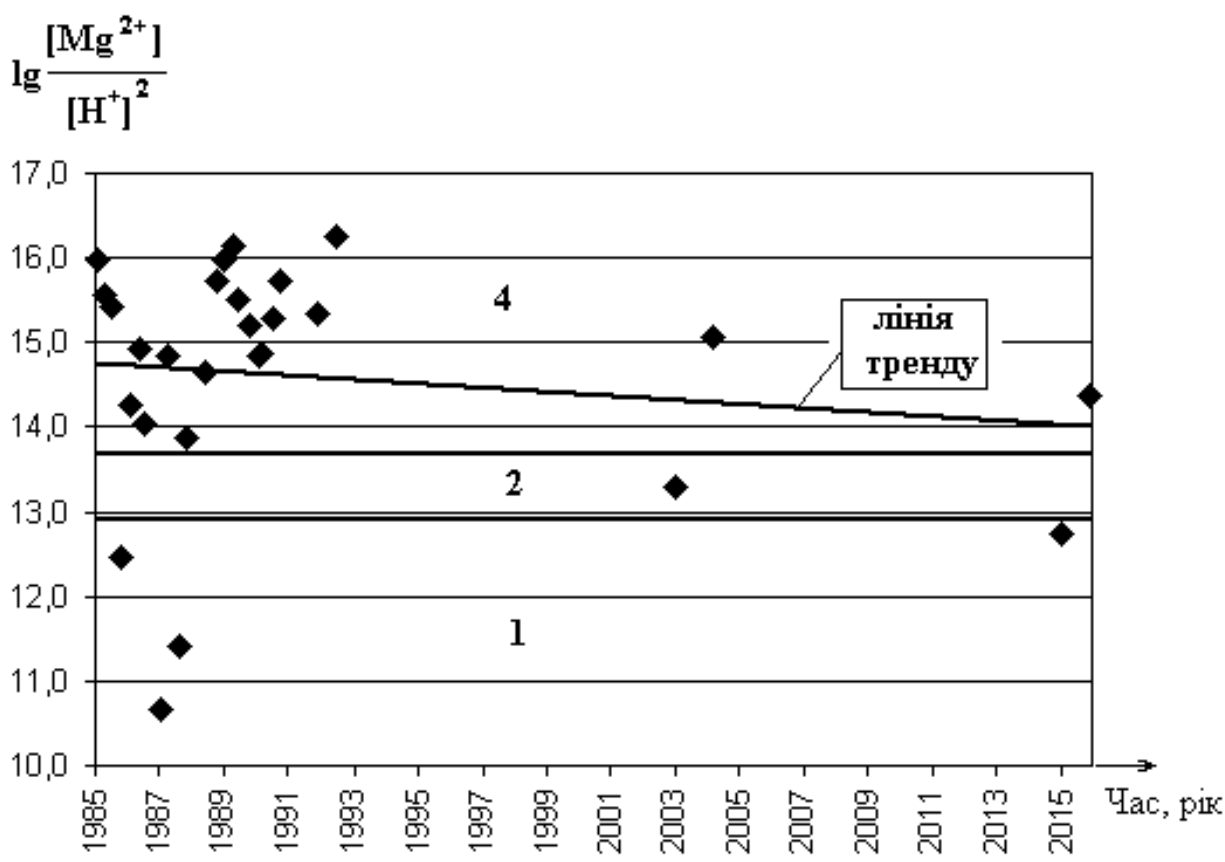

Рис. 2. Графік змін у часі системи $\mathrm{HCl}-\mathrm{H}_{2} \mathrm{O}-\mathrm{Na}_{2} \mathrm{O}-\mathrm{MgO}-\mathrm{SiO}_{2}$ за $\mathrm{t}=25{ }^{0} \mathrm{C}$ i $\lg \left[\mathrm{H}_{4} \mathrm{SiO}_{4}\right]=-3,99$ з нанесеними даними аналізів проб води зі св. № 1052 (ПівнГЗК) за час спостережень, 1985 - 2016 рр.

Як відмічалося вище, процес каолітизації (рівняння 4) потребує хімічної енергії, він нетиповий для підземних вод. На території дослідження цей процес переважає. У всіх пробах води із свердловин відмічається, що гіпергенні процеси мають нестаціонарний характер і з часом посилюються. Так, у воді із свердловини № 1052 (рис. 1), у якій зафіксовані рівноваги 3 хлоритом, лінія тренду вказує на наближення до рівноваг із монтморилонітом.

Наслідком посилення гіпергенних процесів у воді водоносного горизонту четвертинних відкладів є збільшення вмісту іона магнію та жорсткості води. У той же час проведені розрахунки вказують, що наявність іона натрію у воді - це наслідок фільтраційних втрат із хвостосховища ПівнГЗК та, можливо, із хвостосховища балки «Щербаківська», які належить Східному ГЗК.

Висновки. Розрахунками доведено активізацію гіпергенних процесів у воді водоносного горизонту четвертинних відкладів на території ПівнГЗК до встановлення рівноваг із каолінітом, що спричинює збільшення мінералізації грунтових вод, вмісту іона магнію та жорсткості.

Фізико-хімічні процеси у грунтових водах досить складні та потребують постійного моніторингу, включно з аналізом та прогнозом гідрогеохімічних умов.

\section{Бібліографічні посилання}

Grimaud D, Beaucaire C, Michard G, 1990. Modelling of the evolution of ground waters in a granite system at low temperature: the Stripa ground waters, Sweden. Applied Geochemistry 5, 515-525.

Köhler S J, Dufaud F, Oelkers E H, 2003. An experimental study of illite dissolution kinetics as a function of $\mathrm{pH}$ from 1.4 to 12.4 and temperature from 5 to $50^{\circ} \mathrm{C}$. Geochimica et Cosmochimica Acta, 67, 35833594.Korzhinskiy D.S. 1982. Teoriya metasomaticheskoy zonalnosti [The theory of metasomatic zoning]. Moskva: Nauka (in Russian).

Perelman A.I. 1966. Geohimiya landshafta [Geochemistry of the landscape]. Moskva: Vyisshaya shkola (in Russian).

Sherstyuk N.P., Nosova L.O. 2016. Analiz khimichnoho skladu pidzemnykh vod vodonosnykh horyzontiv chetvertynnykh vidkladiv terytoriyi Pivnichnoho hirnychozbahachuval'noho kombinatu (Kryvbas) [Analysis of the chemical composition of the groundwater aquifers of quaternary sediments in Northern mining and processing enterprise (Kryvbas)]. Bulletin of Dnipropetrovsk. Series: Geology. Geography, 18, $151-157$ (in Ukrain).

Shvarcev S.L. 1988. Gidrogeohimija zony gipregeneza [Hydrogeochemistry of the zone of hyphenesis]. Moskva: Nedra (in Russian). 
Tjutjunova F.I. 1987. Gidrogeohimija tehnogeneza [Hydrogeochemistry of technogenesis]. Moskva: Nauka (in Russian).

White W M. 2013. Geochemistry. Oxford, UK: Wiley-Blackwell.
Zverev V.P. 1982. Rol' podzemnyh vod v migracii himicheskih jelementov [The role of groundwater in the migration of chemical elements]. Moskva: Nedra (in Russian).

Надійшла до редколегї 4.04.2017

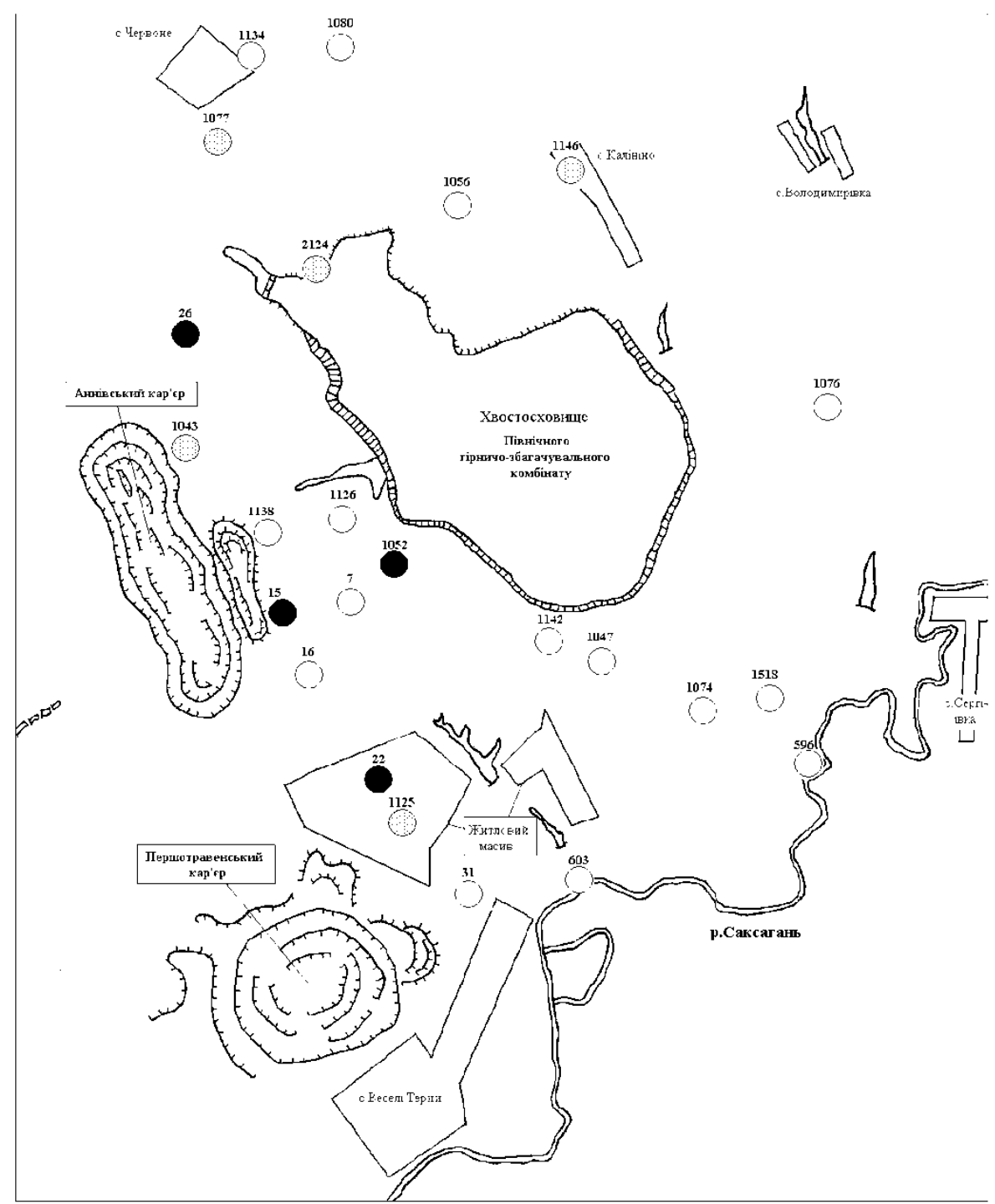

Рис. 3. Карта-схема перебігу процесів гідролізу у воді водоносного горизонту четвертинних відкладів на території ПівнГЗК, березень 2016 р.

\section{Умовні позначення:}

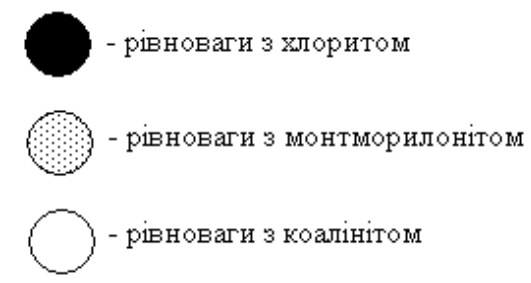

$p$ 


\section{MICT}

Бондар О.В., Самойленко Г.Л. Остракоди крайових частин Борисфенської затоки Східного Паратетису в середньому сарматі.

Євграшкіна Г.П., Горб А.С., Доценко Л.В. Математичні моделі зміни гідрогеологічних умов територій, прилеглих до ставків-накопичувачів скидних шахтних вод..........12 Жолудєв С.В. Обгрунтування технологічної реалізації енергетичного модуля підземного спалювання вугілля........................................................... 19 Жолудєв С.В. Урахування фазових перетворень високотемпературних підземних вод під час оцінювання їх енергетичної ефективності рухливого теплоносія................26 Манюк В.В., Масенко А.В. Геологічна пам’ятка природи «Висачківський соляний

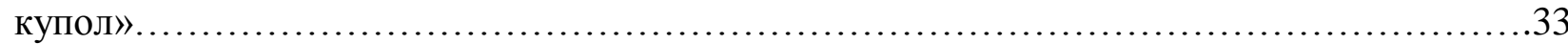

Машіка Г.В. Механізм розроблення критеріїв районування Карпатського регіону з урахуванням основних чинників формування господарського потенціалу......................41 Пономар В.П., Дудченко Н.О., Брик О.Б. Кінетичні параметри процесу відновлення гематиту до магнетиту за допомогою біомаси.......................................53 Савчук В.С., Приходченко В.Ф., Приходченко Д.В.,ТолубецьД.В. Особливості складу вугільних пластів світи $\mathrm{C}_{1}^{4}$ Донецького басейну .............................63 Решетняк Д.Є. Методи оцінювання антропогенних загроз біорізноманіттю прісновод-

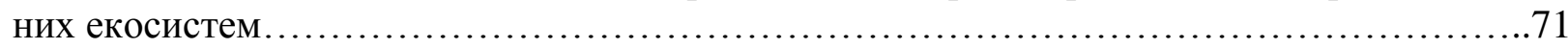
Рябоконь Т.С. Комплекси форамініфер палеоцену Північної України....................80 Савченко Т.С., Дудченко Н.О., Брик О.Б. Перетворення гематиту та гетиту на магнетит у водному середовищі за дії мікрохвильового випромінювання.....................93 Сіренко О.А. Субаеральні відклади еоплейстоцену - нижнього неоплейстоцену рівнинної частини України та їх палінологічна характеристика........................... 101 Швайко В.М., Манюк Вад.В. Структурування екомережі на субрегіональному рівні (Покровський та Межівський райони) Дніпропетровської області). Шерстюк Н.П. Активізація гіпергенних процесів у водоносних горизонтах районів видобутку корисних копалин (на прикладі Північного гірничо-збагачувального комбінату,

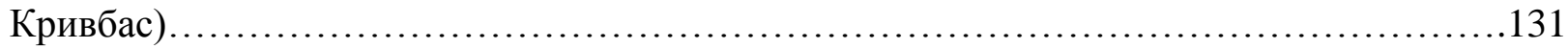




\section{CONTENTS}

Bondar O.V., Samoilenko H.L. Ostracoda of the marginal parts of the Borisphen Gulf ot the Eastern Paratethys in the Middle Sarmatian.......................................................... Yevgrashkina G.P., Gorb A.S., Docenko L.V. Mathematical models of changes in hydro-geological conditions of territories adjacent to tailing ponds of discharged mine water.....................12 Zholudiev S.V. Technological realization of the energetic module which is based on underground coal combustion.

Zholudiev S.V. Calculation of phase transformation of groundwater when evaluating its efficiency

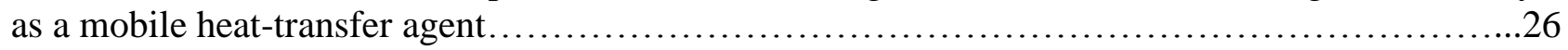

Manyuk V.V., Masenko A.V. The geological nature monument «Vysachkivskyi salt dome»......33 Mashika H.V. Mechanism design criteria for zoning of the Carpathian region in view of the major factors in the formation of economic potential............................................. Ponomar V.P., Dudchenko N.E., Brik A.B. Kinetics of hematite to magnetite reduction by

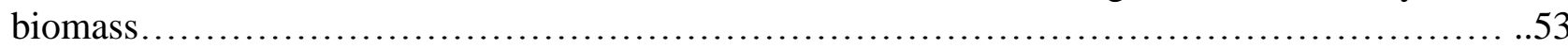

Savchuk V., Prykhodchenko V., Prykhodchenko D., Tolubets D. Features composition of coal

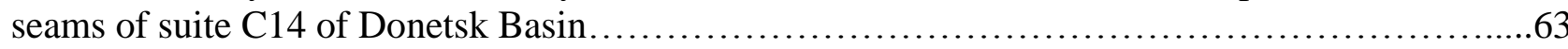
Reshetniak D.Y. Methods for assessing anthropogenic threats to freshwater ecosystems biodiversity

Ryabokon T.S. Foraminiferal assemblages of the Paleocene of Northern Ukraine...................80 Savchenko T.S., Dudchenko N.O., Brik A.B. Transformation of hematite and goethite to magne-tite in aqueous medium under microwave radiation..........................................93 Sirenko O.A. Subaeral Eopleistocene - Lower Neopleistocene deposits of the plain part of Ukraine and their palynological characteristic. Shvaiko V.M., Manyuk V.V. The Ecological Network of the subregional level of Dnipropetrovsk region (Pokrovsky and Mezhyvsky districts) ..........................................119 Sherstyuk N.P. Activation of supergene processes in aquifers mining areas (for example the North mining and processing plant, Kryvbas).... 